University for Business and Technology in Kosovo

UBT Knowledge Center

Oct 28th, 11:00 AM - 12:30 PM

\title{
Challenges to Internal Audit in Public Sector Organizations
}

Plamen Iliev

New Bulgarian University

Follow this and additional works at: https://knowledgecenter.ubt-uni.net/conference

Part of the Business Commons

\section{Recommended Citation}

Iliev, Plamen, "Challenges to Internal Audit in Public Sector Organizations" (2017). UBT International Conference. 234.

https://knowledgecenter.ubt-uni.net/conference/2017/all-events/234

This Event is brought to you for free and open access by the Publication and Journals at UBT Knowledge Center. It has been accepted for inclusion in UBT International Conference by an authorized administrator of UBT Knowledge Center. For more information, please contact knowledge.center@ubt-uni.net. 


\title{
Challenges to Internal Audit in Public Sector Organizations
}

\author{
Plamen Iliev \\ New Bulgarian University \\ Sofia, Bulgaria
}

\begin{abstract}
The report addresses the problems and challenges of internal audit, particularly in public sector organizations. Attention is drawn to the ten-year experience of it is implementation, it is weaknesses and suggestions for overcoming it, as well as the reporting problems, stages and levels to preserve the independence of the internal audit. Considerations have already been made in this direction, as well as expected ones, incl. and developing a strategy for the development and improvement of internal auditing in the future, along with the so-called three lines of protection and the expected benefits of this.
\end{abstract}

Key words: internal audit; public sector; independence; financial management; control

\section{Introduction}

Ten functioning of these organizations in accordance with the principles of sound financial management and the requirements of the legislation. An analysis of the internal audit activity shows that few successes have been achieved, despite a number of issues related to its organizational and functional build-up years after the introduction of the internal audit in the public sector organizations of the Republic of Bulgaria we can accept it as an effective activity to ensure the optimal.

The Internal Audit Units (IAUs) in the Public sector (PS) organizations are already working in line with the requirements of international standards and have adopted the ideas of continually improving the quality of their operations. Internal auditors in their work implement a systematic and disciplinary approach to a uniform and unified methodology and professional standards to determine audit objectives and audit risks. In the internal audit, familiar levels of the audit process are implemented and respected - planning, checking, reporting and tracking written recommendations. For this purpose, methods of effective control / organoleptic methods, documentary methods, modeling methods, computational and analytical methods, etc., are used for the purposes of collecting audit evidence and expressing an independent audit opinion for assurance through the audit report or for consultation of the head of the organization.

\section{Requirements for Internal Audit}

The implementation of the internal audit in the public sector is related to the observance of the main principles of the internal audit, such as:

- Independence and objectivity or internal audit work should be independent and internal auditors must be objective in the performance of their work. Ensuring the independence 
of the internal audit implies that the head of the internal audit should report at such a level in the organization that allows the internal audit unit to perform its duties. Internal auditors must have an unbiased and impartial attitude and avoid conflicts of interest;

- Competence and professional care or internal auditors have the necessary knowledge, skills and other abilities to fulfill their individual responsibilities. They must provide only those services for which they have the necessary knowledge, skills and experience and are in compliance with the Internal Audit Act in Public Sector (IAAPP) and the International Standards for Professional Internal Audit Practice (ISPPIA). Internal auditors should take care and skills that are expected from a reasonably prudent and competent internal audit;

- Integrity and confidentiality, or internal auditors, should build trust that creates a basis for the reliability of their judgment. Confidentiality requires internal auditors to respect the value and ownership of the information they receive in the course of their work and not to disclose information without being authorized to do so unless they have a legal or professional duty to do so.

\section{Internal Audit issues}

However, there are still some problems in the organization and effective functioning of internal audit in public sector organizations in the country, and one of them is in regulating and carrying the management responsibility of the heads of the PC regarding the management of the internal audit. It is necessary to compare or relate to the possibilities to minimize the impact of the management subjectivism towards the functioning of the internal audit in these organizations in accordance with the requirements of the international standards and good practices in this respect and to what extent the requirements of the international standards for ensuring the independence of the internal audit and limiting its scope.

Currently, in the Republic of Bulgaria, the guidelines of the Internal Auditors Institute (IAI) regarding internal auditing in public sector organizations are legislatively regulated in the Public Sector Internal Audit Act. In practice, this law regulates the nature, principles and scope of internal auditing in public sector organizations, the status and functions of structures and individuals implementing it, or it incorporates into the Bulgarian public sector practice the international framework of the IAI for internal audit. In addition to the law, the International Standards for Professional Practice on Internal Audit and the Internal Audit Manual issued by the Ministry of Finance are adopted and applied in our country.

Both in the Standards and in the Law leading to the organization and implementation of the internal audit is its independence. Standards 1100 and 1110 state that "the internal audit must be independent and internal auditors must be objective in the performance of the work" and that no one can interfere in their work, independence is a lack of circumstances, which threaten the ability of the internal audit or its manager to perform its functions in an unbiased manner.

The IAAPP also regulates the principle of independence as a leader in conducting internal audit work in public sector organizations.

Thus, it is necessary to conclude that the problem of the independence of internal audit is key and directly dependent on the management's understanding of public sector organizations about its role, place and importance for effective governance, and corresponds to the leadership's commitment to their managerial responsibility.

The Financial Management and Control Act in the Public Sector (FMCAPC) defines management responsibility and regulates the responsibilities of the managers of the public sector organizations for its implementation, including the provision of the internal audit function in accordance with the legislation in force. In accordance with the FMCAPC and The methodological instructions of the Minister of Finance, management responsibility can be defined as an obligation of the managers to carry out certain activities aimed at Reaching goals 
of the organization by carrying out every action, observing the principles of legality, sound financial management and transparency, including to account for their actions.

In this respect, the line of reporting by the Head of Internal Audit to the Head of the Organization and the Audit Committee, or in other words, must be reported at a level of the organization that allows the Internal Audit to fulfill its responsibilities. International standarts for professional practice in internal audit indicate that in order to ensure the organizational and functional independence of the internal audit it is necessary for the Head of Internal Audit to report functionally and administratively at different levels of the organization. Otherwise, focusing the internal audit reporting lines on a single person - the organization's manager may lead to exposure to internal audit risk by impairing independence, objectivity and narrowing the scope. (Maybe this is the case with the CCB - Corporate Commercial Bank, though not from the $\mathrm{PC}$, but as a public interest organization).

There are also issues related to objectivity, scope, quality of audit activity, especially in the internal audit of municipalities. A major challenge is its ability to help increase the efficiency of public spending and help to build a reliable defense of the interests of the state or the municipality concerned.

\section{Opportunities for internal audit development}

The study of internal audit practices in other EU Member States shows that different ways to develop internal control and internal audit are being implemented: organizing structural reforms in organizations, introducing a double reporting line to audit committees in ministries and municipalities, and before the respective managers to ensure the functional independence of the internal audit, as well as its partial centralization.

\section{A large part of the problems can be solved with some changes in legislation such as:}

- Changes to the current Internal Audit Act in Piblic Sector with regard to the introduction of a mandatory internal audit in public sector organizations to oblige managers in second- and third-degree budget spending organizations to set up an internal audit activity, provided that they manage budgets, for example over 5 million leva;

- Changes in the current legislation regarding the mandatory establishment of Audit Committees and their composition, in all public sector organizations and public interest organizations as a guarantor of the independence and objectivity of internal audit, especially for organizations which, at the discretion of the Minister of Finance are risky and internal audit activities will be particularly sensitive to the lack of separation between functional and administrative reporting;

- Changes to the current IAAPP in terms of clearly identifying lines of functional and administrative internal audit reporting within public sector organizations.

The main efforts regarding the improvement and development of internal audit are focused on the following main areas:

- Improving the quality of the audit activity by conducting external evaluations of internal audit quality by adopting in 2017 the Ordinance - 1 Ministry of finance on the conditions, procedure and manner of conducting external evaluations for ensuring the quality of the audit activity of Public Sector Internal Audit Bodies;

- prepared by the Ministry of finance, a draft for discussion of the Ordinance on the conditions, order and way of organizing and conducting of examinations for obtaining the certificate "internal auditor in the public sector"; 
- updating of the legal framework and the methodology in the field of internal audit: International Standards for Professional Practice on Internal Audit are adopted and applied, amendments are being prepared to the Internal Audit Manual, etc .;

- promoting the legislation and methodology of financial management and control and internal audit by conducting specialized trainings and good practices from EU countries.

In addition, the adoption of the National Strategy for the Development of Financial Management and Control and the Internal Audit in the Public Sector for the period 2017-2020, in which there are provided indicative oriented priorities indicating the respective objectives and measures such as:

1. Strengthening and developing financial management and control in the public sector and increasing the efficiency of the management of public funds;

2. Strengthening the role of internal audit for good financial management in the public sector;

3. Support and assistance from the central harmonization units for the development of the financial management and control and the internal audit in the public sector.

With regard to strengthening the role of the internal audit for good financial management in the PC, it is necessary to:

- Develop and expand the legal framework to increase the effectiveness of internal audit in public sector organizations;

- Adopt a regulation on the procedure for determining the composition and the activity of the audit committees under the Internal Audit Act in Public Sector and the rules for their work;

- Updating the normative acts of the Council of Ministers regulating the internal audit activity in accordance with the amendments made to the Internal Audit Act in the Public Sector and the priority areas for monitoring and control in the country;

- Enhancement of the independence and quality of the internal audit activity through adding value and contributing to the development and improvement of financial management and control;

- Introduction of the internal audit function and structuring of internal audit units in companies with more than 50 percent state or municipal participation in the capital and a certain annual turnover;

- Enable internal quality assessment of internal audit as a way to improve performance;

- Increasing the qualifications and competence of internal auditors and studying and promoting European and international auditing and auditing practices in the public sector through participation in international conferences and workshops.

Regarding the support and support of the central harmonization units (MF) for the development of the financial management and control and the internal audit in the public sector it is necessary:

- Development of guidelines and opinions on the application of new and / or specific requirements of the financial management and control legislation and internal audit in the public sector;

- Issuing / updating instructions from the Minister of Finance for high risk and priority audit areas in relation to the annual planning by the Internal Audit Capabilities;

- Improving the annual reporting process on the status of financial management and control systems and internal audit and coordinating with the central harmonization units the methodological guidelines prepared by the Ministry of finance's specialized directorates to budget managers related to management and control systems;

- Coordination by the Minister of Finance of the appointment and dismissal of internal audit officers and internal auditors in the bodies designated by law and the composition of the audit committees in the organizations designated by law; 
- Annual review and summary of the results of internal audit engagements fulfilled, in accordance with Ministry of finance guidelines for planning of priority / key / audit areas;

- Implement external evaluations of internal audit quality in the public sector, update annual training programs and participate in training and international initiatives, together with representatives of other Member States and the European Commission.

The development and improvement of the financial management and control and the internal audit in the public sector in the Republic of Bulgaria is related to the structuring and implementation of the three lines of protection

The model of the three protection lines provides for an integrated approach to operational management control, the various inspection and control units of the organization and internal audit. In this model, management bodies and senior management are not directly involved, but are the primary users taking into account the process of risk management and control in the organization. The model features can be summarized as follows:

- The first line of protection is related to the direct control of the operational management. It is entrusted with the maintenance of effective internal controls, as part of its duties area related to the day-to-day implementation of control and risk management procedures. The first line of defense includes managerial control, as well as the implementation of internal control measures for which it reports to senior management;

- The second line of protection consists of separate specific structural units with control functions, the main purpose of which is to give assurance of the proper structuring of the first line. Each of these units should be somewhat independent of the operational management (first line), which in their essence is of a managerial nature. In this characteristic, they should have the power to intervene directly in the design and development of internal control systems and risk management. The second line of defense includes units such as financial control, security, risk management, quality, inspection, compliance, again reporting to senior management;

- The third line of protection is expressed and implemented by the internal audit. Internal audit, as an independent and objective entity, reports to the organization's top management on the effectiveness of risk management, internal control and management, and how to achieve the objectives of risk management and internal control.

Introducing the principle of three lines of protection for public funds management will provide additional confidence to managers, the public and external partners for the adequate and lawful functioning of public sector organizations. What we are about to do is to issue guidelines defining the key role of the elements of financial management and control, including the relevant principles on each of the lines of protection.

The expected benefits of introducing the three lines of protection principle are related to identifying, distinguishing and referencing each control activity and risk from individual participants in the organization.

\section{Conclusion}

Regardless of the above mentioned problems, during the ten-year use of the Internal Audit in Bulgaria, it may be concluded that for its further development is nessasary a certain change in the national legislation, in line with that of the EU, is necessary; improving its quality and that of internal control as well as external evaluations of this, including by the Court of Auditors, to improve good financial and other governance in public sector organizations; introducing the three lines of protection, as well as the application of International Standards for Professional Practice. The expected benefits of introducing the three protection lines are related to the identification, 
differentiation and referral of each control activity and risk from the individual participants in the organization.

\section{References:}

1. . Dineva V. - Effectiveness of internal control through the prism of COSO - C. 2015

2. . Dineva V. - Methodological aspects of Internal Audit - Sofia, 2014

3. . Ivanov G. - Financial Management and Control in the Public Sector - S. 2007

4. . Ivanov G. - Responsibilities for Managerial Responsibility and IA in Organizations from PS - Draft Strategy for Development of FMC and HE in PS - C.2017

5. Guidelines and guidelines of the Ministry of Finance for the application of internal control

6. . Weissel A. - Auditing - C. 2017

7. . Independent Financial Audit Act - www.minfin.bg

8. . Internal Audit in the Public Sector Act - www.minfin.bg

9. . Internal Audit Manual (www.minfin.bg)

10. . Financial Management and Control Act in the Public Sector - www.minfin.bg

Abbreviations used:

CCB - Corporate Commercial Bank

EU - European Union

FMCAPC - Financial Management and Control Act in the Public Sector

IA - Internal Audit

IAAPP - Internal Audit Act in Public Sector

IAI - Internal Auditors Institute

ISPPIA - International Standards for Professional Practice in Internal Auditing

MF - Ministry of Finance

PC - Public Sector 